\title{
JURNAL
}

\section{Analisis Kualitas Website Badan Pusat Statistik (BPS) Menggunakan Metode WebQual 4.0 dan Importance - Performance Analysis (IPA)}

\author{
Monica Adelya Putri ${ }^{1)}$, Kartika Gianina Tileng ${ }^{2)}$ \\ Jurusan Information System for Business, Fakultas Teknologi Informasi \\ Universitas Ciputra, Surabaya \\ Email : ${ }^{1}$ monicaadelya21@gmail.com, ${ }^{2}$ kargia@ciputra.ac.id
}

\begin{tabular}{|c|c|c|}
\hline Recieved: 12-07-2021 & $\begin{array}{c}\text { Riwayat artikel: } \\
\text { Revised: 06-09-2021 }\end{array}$ & Accepted: 08-09-2021 \\
\hline
\end{tabular}

\section{Abstract}

The need for data usage in today's era is growing along with the growing interest of researchers and students in doing their assignments. One website that provides reliable statistical data is the Badan Pusat Statistik (BPS). The data searching process requires more time and accuracy. Therefore, the appearance and quality level of a website is considered important factors. A website that is easy for users to understand will greatly help the data search process to be more effective. In this study, the author used WebQual 4.0 and IPA methods by taking researchers who have used the BPS website as this research respondents. Data is collected using online surveys and interview techniques. This study aims to determine the importance level score and the level of performance in the Usability, Information Quality, and Service Quality factors on the BPS website and also map the results of data retrieval into the Cartesian quadrant.

Keywords: Badan Pusat Statistik (BPS), Importance-Performance-Analysis (IPA), Website Quality, WebQual 4.0.

\begin{abstract}
Abstrak
Kebutuhan akan penggunaan data di era ini semakin berkembang seiring dengan semakin meningkatnya minat peneliti dan mahasiswa dalam mengerjakan tugasnya. Salah satu website yang menyediakan data statistik terpercaya adalah Badan Pusat Statistik (BPS). Proses pencarian data membutuhkan lebih banyak waktu dan akurasi. Oleh karena itu, tampilan dan tingkat kualitas sebuah situs web dianggap sebagai faktor penting. Website yang mudah dipahami pengguna akan sangat membantu proses pencarian data menjadi lebih efektif. Dalam penelitian ini penulis menggunakan metode WebQual 4.0 dan IPA dengan mengambil peneliti yang pernah menggunakan website BPS sebagai responden penelitian ini. Data dikumpulkan dengan menggunakan survei online dan teknik wawancara. Penelitian ini bertujuan untuk mengetahui skor tingkat kepentingan dan tingkat kinerja pada faktor Usability, Information Quality, dan Service Quality pada website BPS serta memetakan hasil temu kembali data ke dalam kuadran Cartesian.
\end{abstract}

Kata kunci: Badan Pusat Statistik (BPS), Importance-Performance-Analysis (IPA), kualitas website, WebQual 4.0. 


\section{Pendahuluan}

Dalam dunia pendidikan data statistik menjadi sebuah kebutuhan penting dan seolah wajib bagi para peneliti terutama para pelajar atau mahasiswa pada pengerjaan tugas hingga pada pengerjaan skripsi mereka. Menurut data analisa hasil survei kebutuhan data tahun 2019 oleh BPS sendiri, ditemukan bahawa 65,38\% pengguna layanan website BPS adalah pelajar atau mahasiswa dan peneliti atau dosen sebanyak 6,15 \% [1]. Hal ini membuktikan bahwa dalam dunia Pendidikan data statistik memegang peranan penting dan juga sangat dibutuhkan.

Menurut apa yang disampaikan pada website resmi BPS, BPS hadir untuk mendukung visi presiden dan wakil presiden Republik Indonesia yaitu BPS dapat menjadi website yang menyediakan data statistik berkualitas bagi Indonesia Maju [2]. Sebagai pihak yang sedang membutuhkan data di era yang di mana banyak sekali informasi bertebaran, maka kebutuhan akan informasi yang valid dan akurat menjadi suatu hal yang penting. Dalam prosesnya, pencarian data statistik tidaklah sepenuhnya mudah karena diperlukan ketelitian. Oleh sebab itu, kualitas penyampaian informasi pada website penyedia data haruslah berkualitas dan dapat memberikan kemudahan serta menjawab kebutuhan dari para pencari data.

Pada prosenya penulis tidak menemukan penelitian pada objek yang sejenis, namun penulis menemukan terdapat banyak penelitian terdahulu yang menggunakan metode serupa. Pada penelitian ini metode WebQual 4.0 dan Importance Performance Analysis (IPA) dipilih karena banyak peneliti terdahulu yang sudah menggunakan metode ini sehingga dapat memberikan banyak refrensi untuk melihat dan mengukur bagaimana faktor Kualitas Kegunaan (Usability), Kualitas Informasi (Information Quality) dan Kualitas Layanan (Service Quality) pada website BPS. Sehingga yang menjadi pembeda dari penelitian ini dengan penelitan terdahulu adalah objek penelitian yang digunakan dan juga proses pengambilan data dilakukan dengan cara mengkombinasikan pengisian kuesioner dan menggali feedback secara daring bersama dengan responden.

\section{Kajian Pustaka}

\section{Website}

Menurut Abdullah (2005), website merupakan kumpulan halaman yang di dalamnya terdapat beberapa informasi yang terdiri dari teks, gambar, video, audio, dan visual yang dapat diakses pada internet [3].

\section{WebQual 4.0}

Berdasarkan kutipan dari Iman Sanjaya (2012) WebQual 4.0 adalah sebuah metode untuk mengukur kualitas website berdasarkan persepsi pengguna akhir. WebQual sudah mulai dikembangkan sejak tahun 1998 dan sudah mengalami beberapa interaksi dalam proses penyusunan dimensi serta butir pertanyaannya. 
WebQual 4.0 disusun berdasarkan penelitian pada tiga area (dimensi) kualitas sebagaimana termuat dalam Tabel 1 sampai Tabel 3 [4].

Tabel 1 Aspek Kualitas Kegunaan

\begin{tabular}{lcl}
\hline No & Kode Variabel & \multicolumn{1}{c}{ Usability (Aspek Kualitas Kegunaan) } \\
\hline 1 & US1 & $\begin{array}{l}\text { Atribut Item } \\
\text { Statistik (BPS). }\end{array}$ \\
\hline 2 & US2 & $\begin{array}{l}\text { Saya merasa mudah untuk menggunakan website Badan } \\
\text { Pusat Statistik (BPS) }\end{array}$ \\
\hline 3 & US3 & $\begin{array}{l}\text { Saya merasa jelas dalam menggunakan website Badan Pusat } \\
\text { Statistik (BPS). }\end{array}$ \\
\hline 4 & US4 & $\begin{array}{l}\text { Saya merasa mudah memahami penggunaan website Badan } \\
\text { Pusat Statistik (BPS). }\end{array}$ \\
\hline 5 & US5 & $\begin{array}{l}\text { Menurut saya, navigasi dalam website Badan Pusat Statistik } \\
\text { (BPS) sudah jelas untuk dipahami. }\end{array}$ \\
\hline 7 & US6 & $\begin{array}{l}\text { Menurut saya, navigasi dalam website Badan Pusat Statistik } \\
\text { (BPS) mudah untuk dipahami. }\end{array}$ \\
\hline 8 & US7 & $\begin{array}{l}\text { Menurut saya, desain pada website Badan Pusat Statistik } \\
\text { (BPS) sudah sesuai dengan jenis website-nya (Jenis website } \\
\text { penyedia data). }\end{array}$ \\
\hline 9 & US8 & $\begin{array}{l}\text { Menurut saya, website Badan Pusat Statistik (BPS) memiliki } \\
\text { daya saing dengan website yang sejenis. }\end{array}$ \\
\hline
\end{tabular}

Pada Tabel 1. di atas mencantumkan item atribut aspek kualitas kegunaan (Usability) yang dapat membantu untuk menilai tingkat kualitas dari kegunaan yang diberikan oleh website Badan Pusat Statistik (BPS). Lalu pada Tabel 2. dapat kita lihat, tercantum item atribut aspek kualitas informasi (Information Quality) yang dapat membantu untuk menilai tingkat kualitas dari informasi yang diberikan oleh website Badan Pusat Statistik (BPS).

Tabel 2 Aspek Kualitas Informasi

\begin{tabular}{lcl}
\hline & Kode Variabel & $\begin{array}{l}\text { Information Quality } \\
\text { (Aspek Kualitas Informasi) }\end{array}$ \\
\hline No & IQ1 & $\begin{array}{l}\text { Atribut Item } \\
\text { Menurut saya, website Badan Pusat Statistik (BPS) } \\
\text { menyediakan informasi/data yang akurat. }\end{array}$ \\
\hline 1 & IQ2 & $\begin{array}{l}\text { Menurut saya, website Badan Pusat Statistik (BPS) } \\
\text { menyediakan informasi/data yang terpercaya. }\end{array}$ \\
\hline 3 & IQ3 & $\begin{array}{l}\text { Menurut saya, website Badan Pusat Statistik (BPS) } \\
\text { menyediakan informasi/data yang up to date. }\end{array}$ \\
\hline 4 & IQ4 & $\begin{array}{l}\text { Menurut saya, website Badan Pusat Statistik (BPS) } \\
\text { menyediakan informasi/data yang relevan. }\end{array}$ \\
\hline
\end{tabular}




\begin{tabular}{lcl}
\hline 5 & IQ5 & $\begin{array}{l}\text { Menurut saya, website Badan Pusat Statistik (BPS) } \\
\text { menyediakan informasi/data yang mudah dimengerti. }\end{array}$ \\
\hline 6 & IQ6 & $\begin{array}{l}\text { Menurut saya, website Badan Pusat Statistik (BPS) } \\
\text { menyediakan informasi/data yang detail. }\end{array}$ \\
\hline 7 & IQ7 & $\begin{array}{l}\text { Menurut saya, website Badan Pusat Statistik (BPS) } \\
\text { menyajikan informasi/data dalam format yang tepat. }\end{array}$ \\
\hline
\end{tabular}

Pada Tabel 3. di bawah mencantumkan item atribut aspek kualitas layanan (Service Quality) yang dapat membantu untuk menilai tingkat kualitas dari layanan yang diberikan oleh website Badan Pusat Statistik (BPS).

Tabel 3 Aspek Kualitas Layanan

\begin{tabular}{lcl}
\hline & & \multicolumn{1}{c}{$\begin{array}{c}\text { Service Quality } \\
\text { (Aspek Kualitas Layanan) }\end{array}$} \\
\hline No & Kode Variabel & \multicolumn{1}{c}{ Atribut Item } \\
\hline 1 & SQ1 & $\begin{array}{l}\text { Menurut saya, website Badan Pusat Statistik (BPS) } \\
\text { memberikan layanan data yang valid. }\end{array}$ \\
\hline 2 & SQ2 & $\begin{array}{l}\text { Menurut saya, website Badan Pusat Statistik (BPS) } \\
\text { memberikan layanan data yang akurat. }\end{array}$ \\
\hline 3 & SQ3 & $\begin{array}{l}\text { Saya merasa aman ketika mengakses website Badan Pusat } \\
\text { Statistik (BPS). }\end{array}$ \\
\hline 4 & SQ4 & $\begin{array}{l}\text { Saya merasa website Badan Pusat Statistik (BPS) memiliki } \\
\text { reputasi yang baik. }\end{array}$ \\
\hline 5 & SQ5 & $\begin{array}{l}\text { Saya merasa yakin bahwa kualitas layanan yang diberikan oleh } \\
\text { website Badan Pusat Statistik (BPS) berkualitas. }\end{array}$ \\
\hline
\end{tabular}

\section{Importance - Performance Analysis (IPA)}

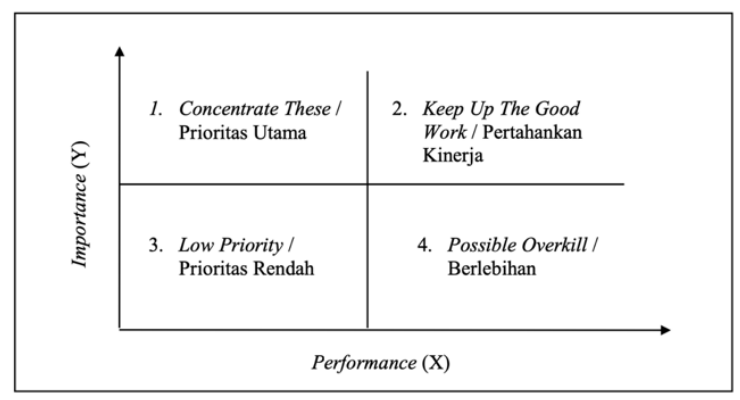

Gambar 1 Diagram/ Kuadran Kartesius[5]

Importance-Performance-Analysis (IPA) adalah sebuah teknik analisis yang telah diperkenalkan oleh John A. Martilla dan John C. James tahun 1977. Teknik ini dipergunakan untuk melakukan identifikasi pada faktor- faktor kinerja penting yang 
harus ditunjukkan oleh suatu organisasi dalam memenuhi kepuasan para pengguna jasa. Tidak hanya diperuntukkan bagi riset dalam bidang pemasaran, namun teknik ini telah digunakan pada berbagai macam bidang pelayanan lainnya seperti kesehatan, sekolah dan juga pemerintahan [6]

Teknik ini digunakan untuk melakukan pengukuran terhadap tingkat kesesuaian dalam menganalisis kepuasan pengguna terhadap tingkat kinerja layanan dan hal yang pengguna inginkan serta harapkan. Dalam proses analisis IPA peneliti menggunakan dua model perhitungan analisis, yaitu analisis kesesuaian dan analisis kesenjangan (GAP). Hasil akhir perhitungan nantinya akan dipetakan kedalam kuadran diagram Kartesius seperti pada Gambar 1. Terdapat 4 kuadran. Kuadran I (Concentrate These/Prioritas Utama), kuadran II (Keep Up The Good Work/ Pertahankan Kinerja), kuadran III (Low Priority/Prioritas Rendah), kuadran IV (Possible Overkill/ Berlebihan) dimana sumbu X merujuk pada tingkat kinerja sementara sumbu Y merujuk pada tingkat kepentingan [3].

\section{Tingkat Kepentingan}

Tingkat kepentingan merupakan sebuah ukuran untuk dapat melihat seberapa penting keberadaan suatu fitur di dalam website terkait menurut para pengguna [6].

\section{Tingkat Kinerja}

Tingkat kinerja yang merupakan sebuah ukuran untuk dapat melihat seberapa baik performa dari fungsi fitur pada sebuah website yang dapat dirasakan oleh pengguna [6].

\section{Badan Pusat Statistik (BPS)}

Badan Pusat Statistik merupakan sebuah Lembaga Pemerintah Non Kementerian yang memiliki tanggung jawab langsung kepada presiden. Untuk turut berpartisipasi dalam pencapaian visi presiden serta wakil presiden maka Badan Pusat Statistik memiliki visi di tahun 2020-2024 untuk menjadi "Penyedia Data Statistik Berkualitas untuk Indonesia Maju" [7].

\section{Metode Penelitian}

Dalam penelitian ini terdapat alur penelitian yang berguna untuk dapat menggambarkan proses pada suatu penelitian dan menjadi pedoman suatu penelitian . 


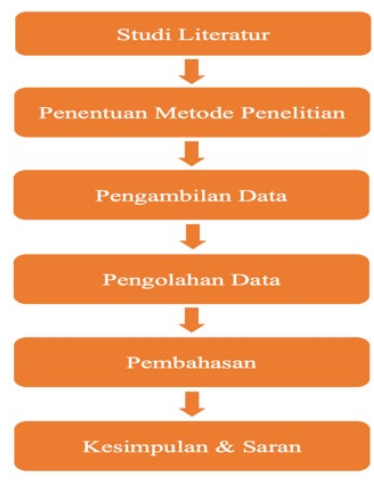

Gambar 2 Alur Penelitian

\section{Studi Literatur}

Tahap ini adalah tahap dimana peneliti dapat memperkuat penelitiannya menggunakan sumber seperti jurnal nasional maupun internasional, hasil pencarian di internet, dan juga hasil penelitian yang telah ada sebelumnya, yang sesuai dan mendukung penelitian tersebut. Dalam tahap ini penulis akan menelaah kepustakaan yang diperlukan dengan lebih tekun dan mendalam [8].

\section{Penentuan Metode Penelitian}

Dalam penelitian ini, penulis memilih untuk melakukan pengumpulan data dengan menggunakan metode WebQual 4.0 dan juga melakukan pengelolaan data menggunakan teknik Importance - Performance Analysis (IPA).

\section{Pengambilan Data}

Proses pengambilan data adalah proses yang umum dilakukan pada sebuah penelitian dengan tujuan mengambil data menggunakan kuesioner dan kemudian hasil yang terkumpul akan dianalisis.

\section{Subjek Penelitian}

Pengambilan sampel dilakukan dengan metode Purposive Judgemental Sampling, dimana sampel dipilih berdasarkan kriteria dan pertimbangan khusus [9]yaitu sampel yang merupakan orang yang sudah pernah menggunakan website Badan Pusat Statistik (BPS) untuk kepentingan pencarian data dalam penelitian. Di dalamnya terdapat mahasiswa, dosen dan entrepreneur. Menurut Sunaryo, jumlah data yang diperlukan dalam uji validitas dan juga uji reliabilitas, sebaiknya adalah dengan jumlah minimal 30 responden. Lalu untuk antisipasi kegagalan maka sebaiknya dilakukan dengan lebih dari 30 responden [10]. Maka pada penelitian ini jumlah sampel yang dipilih adalah sebanyak 55 responden.

2. Penyusunan Kuesioner

Kuesioner yang di gunakan pada penelitian ini disusun berdasarkan metode WebQual 4.0 dan terdapat 21 item atribut di dalamnya. Kuesioner ini terbagi 
kedalam 3 aspek penilaian yaitu dari aspek kualitas kegunaan (Usability), aspek kualitas informasi (Information Quality), dan aspek kualitas layanan (Service Quality) yang juga akan dinilai berdasarkan 2 skala yaitu skala kinerja (Performance) dan juga skala kepentingan (Importance) melalui Skala Likert yang merupakan sebuah skala untuk mengukur persepsi dan juga pendapat satu atau beberapa orang mengenai sesuatu hal [11].

\section{Pengolahan Data}

Setelah seluruh data diperoleh, maka selanjutnya seluruh data diolah untuk mengetahui hasil dan kesimpulan dari seluruh data responden yang dikumpulkan.

1. Uji Validitas

Menurut Sugiyono (2014), uji validitas adalah sebuah alat uji yang akan menunjukan derajat ketepatan diantara data yang sesungguhnya dengan data yang telah berhasil dikumpulkan oleh peneliti [12]. Suatu instrumen dapat dikatakan valid bila nilai signifikansi nya $<0.05$ [13]. Dalam penelitian Uji validitas yang membandingkan $r$ hitung dan $r$ tabel dikatakan valid jika nilai $r$ hitung lebih besar dari pada $r$ tabel dengan tingkat signifikansi 5\% jika dibandingkan menggunakan degree of freedom $(\mathrm{df})=\mathrm{n}-2$, dan $\mathrm{n}$ merupakan jumlah sampel

2. Uji Reliabilitas

Sebuah penelitian dapat dikatakan reliabel, jika nilai Cronbach Alpha $>0.70$ [13].

3. Analisis Kesesuaian

Melalui analisis kesesuaian, peneliti akan dapat melihat item atribut manakah yang dapat dijadikan prioritas dalam penelitian [15].

$$
T K_{i}=\frac{\sum x i}{\sum y o} \times 100 \%
$$

Penjelasan:

$$
\begin{array}{ll}
\text { TKi } & : \text { Tingkat kesesuaian responden } \\
\sum X i & : \text { Skor penilaian kinerja } \\
\sum Y i & : \text { Skor penilaian kepentingan }
\end{array}
$$

4. Analisis Kesenjangan (GAP)

Dengan menggunakan analisis kesenjangan (GAP) peneliti dapat menilai perbedaan antara kepuasan pengguna dengan kinerja website itu sendiri [15].

$$
Q_{i}=\text { Performance }_{i}-\text { Importance }_{i}
$$


Penjelasan:

Qi : Tingkat kesenjangan

Performancei : Hasil nilai rata - rata tingkat kinerja

Importancei : Hasil nilai rata - rata tingkat kepentingan

5. Menghitung rata - rata penilaian

Penilaian rata - rata akan didapatkan dari hasil peritungan kuesioner yang telah diisi oleh responden dan kemudian digunakan dalam perhitungan rumus tingkat kesenjangan (GAP) [15].

$$
\begin{aligned}
& \bar{X}=\frac{X i}{n} \\
& \bar{Y}=\frac{Y i}{n}
\end{aligned}
$$

Penjelasan:

$\begin{array}{ll}\mathrm{x} & \text { : Nilai rata - rata tingkat kinerja } \\ \mathrm{y} & \text { : Nilai rata - rata tingkat kepentingan } \\ \mathrm{Xi} & \text { : Jumlah nilai per atribut item tingkat kinerja } \\ \mathrm{Yi} & \text { :Jumlah nilai per atribut item tingkat kepentingan } \\ \mathrm{n} & \text { : Jumlah }\end{array}$

6. Analisis Kuadran Diagram Kartesius

Untuk dapat memetakan hasil pada kuadran diagram Kartesius maka diperlukan perhitungan dengan rumus sebagai berikut [15]:

$$
\begin{aligned}
& \text { Sumbu } \bar{X}=\frac{\sum_{i=1}^{N} \overline{X \imath}}{k} \\
& \text { Sumbu } \bar{Y}=\frac{\sum_{i=1}^{N} \overline{Y l}}{k}
\end{aligned}
$$

Penjelasan:

Sumbu $X$ : Titik tingkat kepentingan

Sumbu $Y$ : Titik tingkat kinerja

$k \quad:$ Total atribut

\section{Hasil dan Pembahasan}

\section{Hasil analisis Demografis}

Pada proses penelitian ini, peneliti telah mengambil data dari 55 responden yang pernah menggunakan dan mendapatkan data dari website Badan Pusat Statistik (BPS) untuk dilakukan analisis demografis jenis kelamin, program studi, frekuensi penggunaan website Badan Pusat Statistik (BPS) di dalam kurun waktu 1 bulan, dan alasan menggunakan website Badan Pusat Statistik (BPS). Dan data-data tersebut dapat dilihat pada diagram dibawah ini: 
a) Jenis Kelamin

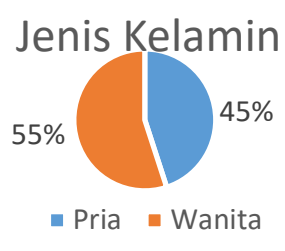

Gambar 3 Diagram jenis kelamin

Diagram pada Gambar 3 di atas menyatakan bahwa dari 55 orang responden yang diambil 55\% responden adalah wanita dan $45 \%$ lainnya merupakan responden pria.

b) Program Studi Responden

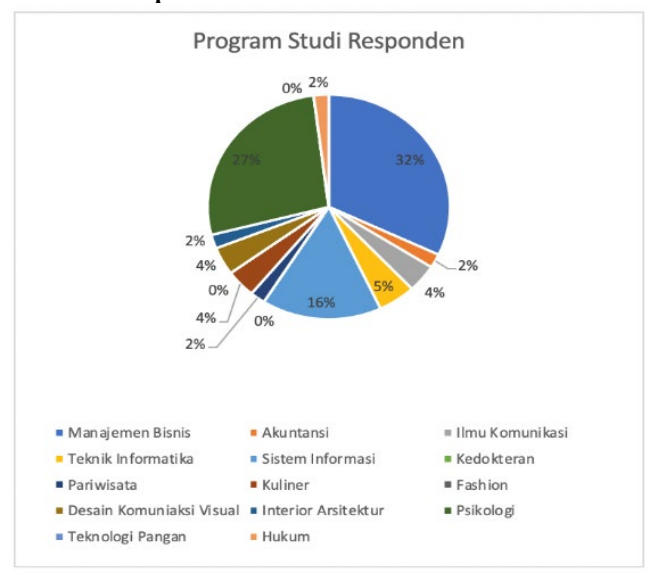

Gambar 4 Diagram program studi responden

Gambar 4 merujuk pada jurusan atau program studi setiap responden. Responden yang terbanyak adalah dari program studi Manajemen Bisnis dengan jumlah 32\%, lalu responden terbanyak berikutnya adalah dari program studi Psikologi sebanyak 27\% dan Sistem Informasi sebanyak 16\%, Teknik Informatika sebanyak 5\%, lalu masing - masing program studi Kuliner, Desain Komunikasi Visual, Ilmu Komunikasi sebanyak 4\%, Pariwisata, Hukum, Interior Arsitektur dan Akuntansi masing - masing sebanyak $2 \%$ sementara sisanya adalah $0 \%$ yang artinya tidak ada responden yang berasal dari program studi Kedokteran, Fashion, Teknologi Pangan 
c) Frekuensi Penggunaan

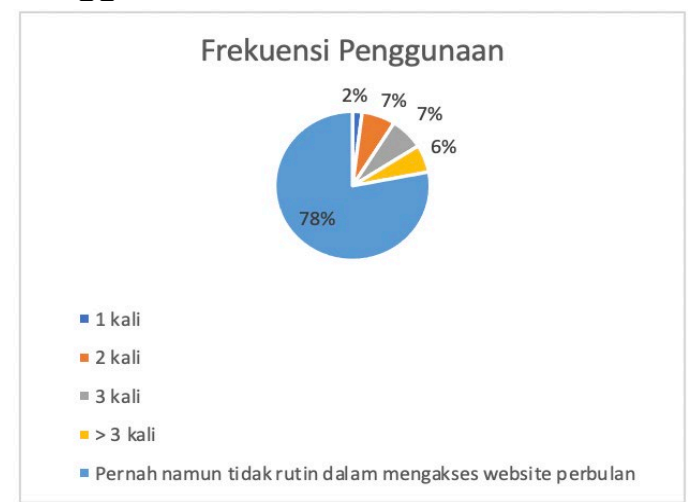

Gambar 5 Diagram frekuensi penggunaan

Diagram Frekuensi penggunaan menunjukkan bahwa 78\% responden pernah menggunakan Website Badan Pusat Statistik (BPS) namun tidak rutin dalam mengakses website dalam kurun waktu 1 bulan. Sementara $7 \%$ responden rutin mengakses sebanyak 2 kali dalam 1 bulan, 7\% responden rutin mengkases website Badan Pusat Statistik (BPS) sebanyak 3 kali dalam sebulan, $6 \%$ responden rutin mengakses website Badan Pusat Statistik (BPS) sebanyak lebih dari (>3) kali dalam sebulan, dan 2\% rutin mengakses website Badan Pusat Statistik (BPS) sebanyak 1 kali dalam sebulan.

d) Tujuan Penggunaan

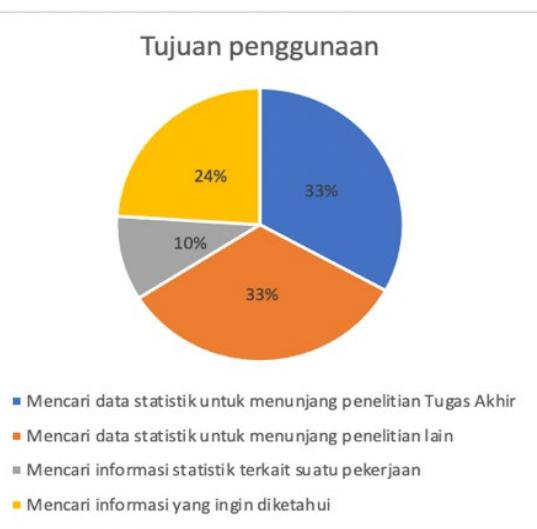

Gambar 6 Diagram tujuan penggunaan website

Hasil pengisian kuesioner pada 55 responden telah menunjukkan hasil bahwa $10 \%$ responden mengakses dan menggunakan website Badan Pusat Statistik (BPS) terkait dengan suatu pekerjaan mereka, sementara responden lain sebesar 24\% memakai website Badan Pusat Statistik (BPS) baik untuk mencari data statistik sebagai informasi yang ingin mereka ketahui, lalu 33\% orang lainnya mengakses website Badan Pusat Statistik (BPS) untuk mencari data yang dapat menunjang penelitian Tugas Akhir dan terakhir adalah 
responden yang mengakses website Badan Pusat Statistik(BPS) dengan tujuan mencari data statistik untuk menunjang penelitian lain ada sebanayak $33 \%$.

\section{Uji Validitas}

Tabel 4 Hasil Uji Validitas Tingkat Kinerja

\begin{tabular}{|c|c|c|c|c|}
\hline \multicolumn{2}{|l|}{ Variabel } & \multirow[b]{2}{*}{ R Hitung } & \multirow[b]{2}{*}{ R Tabel } & \multirow[b]{2}{*}{ Hasil } \\
\hline Kategori Aspek Penilaian & $\begin{array}{c}\text { Kode } \\
\text { Variabel }\end{array}$ & & & \\
\hline \multirow{9}{*}{ Kualitas Kegunaan (Usability) } & US1 & 0.662 & 0.265 & Valid \\
\hline & US2 & 0.611 & 0.265 & Valid \\
\hline & US3 & 0.601 & 0.265 & Valid \\
\hline & US4 & 0.577 & 0.265 & Valid \\
\hline & US5 & 0.381 & 0.265 & Valid \\
\hline & US6 & 0.562 & 0.265 & Valid \\
\hline & US7 & 0.504 & 0.265 & Valid \\
\hline & US8 & 0.308 & 0.265 & Valid \\
\hline & US9 & 0.610 & 0.265 & Valid \\
\hline \multirow{7}{*}{$\begin{array}{l}\text { Kualitas Informasi (Information } \\
\text { Quality) }\end{array}$} & IQ1 & 0.547 & 0.265 & Valid \\
\hline & IQ2 & 0.507 & 0.265 & Valid \\
\hline & IQ3 & 0.414 & 0.265 & Valid \\
\hline & IQ4 & 0.544 & 0.265 & Valid \\
\hline & IQ5 & 0.499 & 0.265 & Valid \\
\hline & IQ6 & 0.387 & 0.265 & Valid \\
\hline & IQ7 & 0.535 & 0.265 & Valid \\
\hline \multirow{5}{*}{ Kualitas Layanan (Service Quality) } & SQ1 & 0.451 & 0.265 & Valid \\
\hline & SQ2 & 0.544 & 0.265 & Valid \\
\hline & SQ3 & 0.589 & 0.265 & Valid \\
\hline & SQ4 & 0.679 & 0.265 & Valid \\
\hline & SQ5 & 0.701 & 0.265 & Valid \\
\hline
\end{tabular}

Dalam melakukan uji validitas ini, peneliti mendapatkan angka $r$ tabel 0.265 menggunakan rumus $\mathrm{Df}=\mathrm{n}-2$ dengan nilai signifikansi 0.05 dari jumlah total responden 55 orang.

Tabel 5 Hasil Uji Validitas Tingkat Kepentingan

\begin{tabular}{lcccc}
\hline \multicolumn{1}{c}{ Variabel } & & R Hitung & R Tabel & Hasil \\
\hline Kategori Aspek Penilaian & $\begin{array}{c}\text { Kode } \\
\text { Variabel }\end{array}$ & R & \\
\cline { 2 - 4 } & US1 & 0.662 & 0.265 & Valid \\
\cline { 2 - 4 } & US2 & 0.611 & 0.265 & Valid \\
\cline { 2 - 4 } $\begin{array}{l}\text { Kualitas Kegunaan } \\
\text { (Usability) }\end{array}$ & US4 & 0.601 & 0.265 & Valid \\
\cline { 2 - 4 } & US5 & 0.577 & 0.265 & Valid \\
\cline { 2 - 4 } & US6 & 0.562 & 0.265 & Valid \\
\cline { 2 - 4 } & US7 & 0.504 & 0.265 & Valid \\
\cline { 2 - 5 } & US8 & 0.308 & 0.265 & Valid \\
\hline
\end{tabular}




\begin{tabular}{|c|c|c|c|c|}
\hline & US9 & 0.610 & 0.265 & Valid \\
\hline \multirow{7}{*}{$\begin{array}{l}\text { Kualitas Informasi } \\
\text { (Information Quality) }\end{array}$} & IQ1 & 0.547 & 0.265 & Valid \\
\hline & IQ2 & 0.507 & 0.265 & Valid \\
\hline & IQ3 & 0.414 & 0.265 & Valid \\
\hline & IQ4 & 0.544 & 0.265 & Valid \\
\hline & IQ5 & 0.499 & 0.265 & Valid \\
\hline & IQ6 & 0.387 & 0.265 & Valid \\
\hline & IQ7 & 0.535 & 0.265 & Valid \\
\hline \multirow{5}{*}{$\begin{array}{l}\text { Kualitas Layanan (Service } \\
\text { Quality) }\end{array}$} & SQ1 & 0.451 & 0.265 & Valid \\
\hline & SQ2 & 0.544 & 0.265 & Valid \\
\hline & SQ3 & 0.589 & 0.265 & Valid \\
\hline & SQ4 & 0.679 & 0.265 & Valid \\
\hline & SQ5 & 0.701 & 0.265 & Valid \\
\hline
\end{tabular}

Instrumen pengujian terhadap tingkat kepentingan bertujuan untuk melihat apakah fitur yang disebutkan pada atribut pernyataan dianggap penting untuk dimiliki oleh sebuah website.

\section{Uji Reliabilitas}

Tabel 6 Hasil Uji Reliabilitas Tingkat Kinerja

\begin{tabular}{|c|c|c|c|c|}
\hline \multicolumn{2}{|c|}{ Variabel } & \multirow[b]{2}{*}{$\begin{array}{l}\text { Alpha } \\
\text { Hitung }\end{array}$} & \multirow[b]{2}{*}{$\begin{array}{l}\text { Cronbach } \\
\text { Alpha }\end{array}$} & \multirow[b]{2}{*}{ Hasil } \\
\hline $\begin{array}{l}\text { Kategori Aspek } \\
\text { Penilaian }\end{array}$ & $\begin{array}{c}\text { Kode } \\
\text { Variabel }\end{array}$ & & & \\
\hline \multirow{9}{*}{$\begin{array}{l}\text { Kualitas Kegunaan } \\
\text { (Usability) }\end{array}$} & US1 & 0.859 & 0.70 & Reliabel \\
\hline & US2 & 0.859 & 0.70 & Reliabel \\
\hline & US3 & 0.860 & 0.70 & Reliabel \\
\hline & US4 & 0.861 & 0.70 & Reliabel \\
\hline & US5 & 0.869 & 0.70 & Reliabel \\
\hline & US6 & 0.862 & 0.70 & Reliabel \\
\hline & US7 & 0.864 & 0.70 & Reliabel \\
\hline & US8 & 0.872 & 0.70 & Reliabel \\
\hline & US9 & 0.860 & 0.70 & Reliabel \\
\hline \multirow{7}{*}{$\begin{array}{l}\text { Kualitas Informasi } \\
\text { (Information } \\
\text { Quality) }\end{array}$} & IQ1 & 0.862 & 0.70 & Reliabel \\
\hline & IQ2 & 0.863 & 0.70 & Reliabel \\
\hline & IQ3 & 0.867 & 0.70 & Reliabel \\
\hline & IQ4 & 0.862 & 0.70 & Reliabel \\
\hline & IQ5 & 0.864 & 0.70 & Reliabel \\
\hline & IQ6 & 0.867 & 0.70 & Reliabel \\
\hline & IQ7 & 0.862 & 0.70 & Reliabel \\
\hline \multirow{5}{*}{$\begin{array}{l}\text { Kualitas Layanan } \\
\text { (Service Quality) }\end{array}$} & SQ1 & 0.865 & 0.70 & Reliabel \\
\hline & SQ2 & 0.862 & 0.70 & Reliabel \\
\hline & SQ3 & 0.861 & 0.70 & Reliabel \\
\hline & SQ4 & 0.856 & 0.70 & Reliabel \\
\hline & SQ5 & 0.856 & 0.70 & Reliabel \\
\hline
\end{tabular}


Berdasarkan hasil uji Reliabilitas diatas, dinyatakan bahwa atribut pernyataan dalam kuesioner reliabel dengan nilai terbesar pada uji ini terdapat pada atribut US8 sebesar 0.872

Tabel 7 Hasil Uji Reliabilitas Tingkat Kepentingan

\begin{tabular}{|c|c|c|c|c|}
\hline \multicolumn{2}{|c|}{ Variabel } & \multirow[b]{2}{*}{$\begin{array}{l}\text { Alpha } \\
\text { Hitung }\end{array}$} & \multirow[b]{2}{*}{$\begin{array}{c}\text { Cronbach } \\
\text { Alpha }\end{array}$} & \multirow[b]{2}{*}{ Hasil } \\
\hline $\begin{array}{l}\text { Kategori Aspek } \\
\text { Penilaian }\end{array}$ & Kode Variabel & & & \\
\hline \multirow{9}{*}{$\begin{array}{l}\text { Kualitas } \\
\text { Kegunaan } \\
\text { (Usability) }\end{array}$} & US1 & 0.869 & 0.70 & Reliabel \\
\hline & US2 & 0.871 & 0.70 & Reliabel \\
\hline & US3 & 0.867 & 0.70 & Reliabel \\
\hline & US4 & 0.869 & 0.70 & Reliabel \\
\hline & US5 & 0.869 & 0.70 & Reliabel \\
\hline & US6 & 0.866 & 0.70 & Reliabel \\
\hline & US7 & 0.866 & 0.70 & Reliabel \\
\hline & US8 & 0.887 & 0.70 & Reliabel \\
\hline & US9 & 0.877 & 0.70 & Reliabel \\
\hline \multirow{7}{*}{$\begin{array}{l}\text { Kualitas } \\
\text { Informasi } \\
\text { (Information } \\
\text { Quality) }\end{array}$} & IQ1 & 0.872 & 0.70 & Reliabel \\
\hline & IQ2 & 0.870 & 0.70 & Reliabel \\
\hline & IQ3 & 0.869 & 0.70 & Reliabel \\
\hline & IQ4 & 0.864 & 0.70 & Reliabel \\
\hline & IQ5 & 0.867 & 0.70 & Reliabel \\
\hline & IQ6 & 0.864 & 0.70 & Reliabel \\
\hline & IQ7 & 0.870 & 0.70 & Reliabel \\
\hline \multirow{5}{*}{$\begin{array}{l}\text { Kualitas Layanan } \\
\text { (Service Quality) }\end{array}$} & SQ1 & 0.871 & 0.70 & Reliabel \\
\hline & SQ2 & 0.869 & 0.70 & Reliabel \\
\hline & SQ3 & 0.877 & 0.70 & Reliabel \\
\hline & SQ4 & 0.867 & 0.70 & Reliabel \\
\hline & SQ5 & 0.868 & 0.70 & Reliabel \\
\hline
\end{tabular}

Pada aspek kepentingan nya, hasil uji reliabilitas menyatakan bahwa atribut pernyataan dalam kuesioner dinyatakan reliabel dengan nilai terbesar pada uji ini terdapat pada atribut US8 sebesar 0.887 .

\section{Importance-Performance Analysis (IPA)}

\section{Analisis Kesesuaian}

Dapat dilihat pada Tabel 8 di bawah bahwa hasil analisis Tingkat Kesesuaian dari sisi kinerja dan kepentingan website Badan Pusat Statistik (BPS) adalah sebesar $87.1 \%$ yang artinya dapat disimpulkan bahwa pelayanan yang diberikan oleh website tidak sesuai harapan pengguna dan kurang memuaskan bagi penggunanya. 
Tabel 8 Hasil Analisis Kesesuaian

\begin{tabular}{|c|c|c|c|c|c|}
\hline \multicolumn{6}{|c|}{ Kualitas Kegunaan (Usability) } \\
\hline \multirow[t]{2}{*}{ No } & \multirow{2}{*}{$\begin{array}{c}\text { Kode } \\
\text { Variabel }\end{array}$} & \multirow{2}{*}{ Atribut Item } & \multicolumn{2}{|c|}{ Perhitungan } & \multirow{2}{*}{$\begin{array}{c}\text { Tingkat } \\
\text { Kesesuaian }\end{array}$} \\
\hline & & & Kinerja & Kepentingan & \\
\hline 1 & US1 & $\begin{array}{l}\text { Saya merasa mudah } \\
\text { untuk } \\
\text { website Badan } \\
\text { Statistik (BPS). Pusat } \\
\end{array}$ & 186 & 251 & $74.4 \%$ \\
\hline 2 & US2 & $\begin{array}{l}\text { Saya merasa mudah } \\
\text { untuk menggunakan } \\
\text { website Badan Pusat } \\
\text { Statistik (BPS). }\end{array}$ & 186 & 263 & $70.7 \%$ \\
\hline 3 & US3 & $\begin{array}{l}\text { Saya merasa jelas dalam } \\
\text { menggunakan } \\
\text { Badan Pusite } \\
\text { (BPS). }\end{array}$ & 184 & 250 & $73.6 \%$ \\
\hline 4 & US4 & $\begin{array}{l}\text { Saya merasa mudah } \\
\text { memahami penggunaan } \\
\text { website Badan Pusat } \\
\text { Statistik (BPS). }\end{array}$ & 173 & 250 & $69.2 \%$ \\
\hline 5 & US5 & \begin{tabular}{lc}
\multicolumn{3}{l}{ Menurut saya, navigasi } \\
dalam website & Badan \\
Pusat Statistik & (BPS) \\
sudah jelas & untuk \\
dipahami. & \\
\end{tabular} & 158 & 252 & $62.7 \%$ \\
\hline 6 & US6 & $\begin{array}{l}\text { Menurut saya, navigasi } \\
\text { dalam website Badan } \\
\text { Pusat Statistik (BPS) } \\
\text { mudah untuk dipahami. }\end{array}$ & 167 & 255 & $65.4 \%$ \\
\hline 7 & US7 & $\begin{array}{l}\text { Menurut saya, desain } \\
\text { pada website Badan } \\
\text { Pusat Statistik (BPS) } \\
\text { sudah sesuai dengan } \\
\text { jenis website-nya (Jenis } \\
\text { website penyedia data). }\end{array}$ & 183 & 242 & $75.6 \%$ \\
\hline 8 & US8 & $\begin{array}{l}\text { Menurut saya, website } \\
\text { Badan Pusat Statistik } \\
\text { (BPS) memiliki daya } \\
\text { saing dengan website } \\
\text { yang sejenis. }\end{array}$ & 181 & 224 & $80.8 \%$ \\
\hline 9 & US9 & $\begin{array}{l}\text { Menurut saya, website } \\
\text { Badan Pusat Statistik } \\
\text { (BPS) memberikan saya } \\
\text { pengalaman penggunaan } \\
\text { yang positif. }\end{array}$ & 201 & 237 & $84.8 \%$ \\
\hline & & Kualitas Informasi ( & nformatio & Quality) & \\
\hline 1 & IQ1 & $\begin{array}{l}\text { Menurut saya, website } \\
\text { Badan Pusat Statistik } \\
\text { (BPS) menyediakan }\end{array}$ & 234 & 267 & $87.6 \%$ \\
\hline
\end{tabular}


AITI: Jurnal Teknologi Informasi

\begin{tabular}{|c|c|c|c|c|c|}
\hline & & $\begin{array}{l}\text { informasi/data } \\
\text { yang akurat. }\end{array}$ & & & \\
\hline 2 & IQ2 & $\begin{array}{l}\text { Menurut saya, website } \\
\text { Badan Pusat Statistik } \\
\text { (BPS) menyediakan } \\
\text { informasi/data yang } \\
\text { terpercaya. }\end{array}$ & 242 & 264 & $91.7 \%$ \\
\hline 3 & IQ3 & $\begin{array}{l}\text { Menurut saya, website } \\
\text { Badan Pusat Statistik } \\
\text { (BPS) menyediakan } \\
\text { informasi/data yang up } \\
\text { to date. }\end{array}$ & 185 & 259 & $71.4 \%$ \\
\hline 4 & IQ4 & $\begin{array}{l}\text { Menurut saya, website } \\
\text { Badan Pusat Statistik } \\
\text { (BPS) menyediakan } \\
\text { informasi/data } \\
\text { yang relevan. }\end{array}$ & 211 & 249 & $84.7 \%$ \\
\hline 5 & IQ5 & $\begin{array}{l}\text { Menurut saya, website } \\
\text { Badan Pusat Statistik } \\
\text { (BPS) menyediakan } \\
\text { informasi/data } \\
\text { yang mudah } \\
\text { dimengerti. }\end{array}$ & 205 & 254 & $80.7 \%$ \\
\hline 6 & IQ6 & $\begin{array}{l}\text { Menurut saya, website } \\
\text { Badan Pusat Statistik } \\
\text { (BPS) menyediakan } \\
\text { informasi/data } \\
\text { yang detail. }\end{array}$ & 211 & 251 & $84.0 \%$ \\
\hline 7 & IQ7 & $\begin{array}{l}\text { Menurut saya, website } \\
\text { Badan Pusat Statistik } \\
\text { (BPS) menyajikan } \\
\text { informasi/data dalam } \\
\text { format yang tepat. }\end{array}$ & 217 & 255 & $85.1 \%$ \\
\hline \multicolumn{6}{|c|}{ Kualitas Layanan (Service Quality) } \\
\hline 1 & SQ1 & $\begin{array}{l}\text { Menurut saya, website } \\
\text { Badan Pusat Statistik } \\
\text { (BPS) memberikan } \\
\text { layanan data yang valid. }\end{array}$ & 231 & 263 & $87.8 \%$ \\
\hline 2 & SQ2 & $\begin{array}{l}\text { Menurut saya, website } \\
\text { Badan Pusat Statistik } \\
\text { (BPS) memberikan } \\
\text { layanan data yang akurat. }\end{array}$ & 229 & 258 & $88.8 \%$ \\
\hline 3 & SQ3 & $\begin{array}{l}\text { Saya merasa aman ketika } \\
\text { mengakses website Badan } \\
\text { Pusat Statistik (BPS). }\end{array}$ & 234 & 254 & $92.1 \%$ \\
\hline 4 & SQ4 & $\begin{array}{l}\text { Saya merasa website } \text { Badan } \\
\text { Pusat Statistik (BPS) } \\
\text { memiliki reputasi yang } \\
\text { baik. }\end{array}$ & 225 & 253 & $88.9 \%$ \\
\hline
\end{tabular}




\begin{tabular}{|c|c|c|c|c|c|}
\hline 5 & SQ5 & $\begin{array}{l}\text { Saya merasa yakin bahwa } \\
\text { kualitas layanan yang } \\
\text { diberikan oleh website } \\
\text { Badan Pusat Statistik } \\
\text { (BPS) berkualitas. }\end{array}$ & 218 & 255 & $85.5 \%$ \\
\hline & & Jumlah: & 4261 & 5306 & $87.1 \%$ \\
\hline
\end{tabular}

Perhitungan Rata - rata

Tabel 9 Hasil perhitungan rata-rata penilaian

\begin{tabular}{lc}
\hline \multicolumn{1}{c}{ Variabel } & $\begin{array}{c}\text { Jumlah Rata - Rata Tingkat } \\
\text { Kinerja (Xi) }\end{array}$ \\
\hline $\begin{array}{l}\text { Sumbu X } \\
\text { (Tingkat Kinerja) }\end{array}$ & 3.69 \\
\hline $\begin{array}{l}\text { Sumbu Y } \\
\text { (Tingkat Kepentingan) }\end{array}$ & 4.59 \\
\hline
\end{tabular}

Hasil perhitungan rata - rata pada tingkat kinerja yang akan digunakan sebagai sumbu (X) dalam analisis diagram Kuadaran Kartesius adalah sebesar 3.69. Sementara untuk hasil perhitungan rata - rata pada tingkat kepentingan yang akan digunakan sebagai sumbu (Y) dalam analisis diagram Kartesius adalah sebesar 4.59.

Analisis Kesesuaian (GAP)

Tabel 10 Hasil Akhir Rata - Rata Nilai Kesenjangan (GAP)

\begin{tabular}{lcccc}
\hline Variabel & $\begin{array}{c}\text { Jumlah Rata - } \\
\text { Rata Tingkat } \\
\text { Kinerja (Xi) }\end{array}$ & $\begin{array}{c}\text { Jumlah Rata - } \\
\text { Rata Tingkat } \\
\text { Kepentingan (Yi) }\end{array}$ & $\begin{array}{c}\text { Nilai } \\
\text { GAP }\end{array}$ & Keterangan \\
\hline $\begin{array}{l}\text { Kualitas Kegunaan } \\
\text { (Usability) }\end{array}$ & 3.27 & 4.49 & -1.22 & Tidak Puas \\
\hline $\begin{array}{l}\text { Kualitas Informasi } \\
\text { (Information Quality) }\end{array}$ & 3.91 & 4.65 & -0.74 & Tidak Puas \\
\hline $\begin{array}{l}\text { Kualitas Layanan } \\
\text { (Service Quality) }\end{array}$ & 4.12 & 4.68 & -0.57 & Tidak Puas \\
\hline \multicolumn{1}{c}{ Total: } & 11.30 & 13.82 & -2.53 & Tidak Puas \\
\hline
\end{tabular}

Hasil akhir rata - rata nilai kesenjangan baik dari aspek Kegunaan (Usability), Kualitas Informasi (Information Quality), dan juga Kualitas Layanan (Service Quality) menunjukkan bahwa sebenarnya masih terdapat kesenjangan diantara harapan pengguna dengan kepuasan pengguna website Badan Pusat Statistik (BPS) terhadap layanan yang sudah ada sampai saat ini. 


\section{Analisis Kuadran Diagram Kartesius}

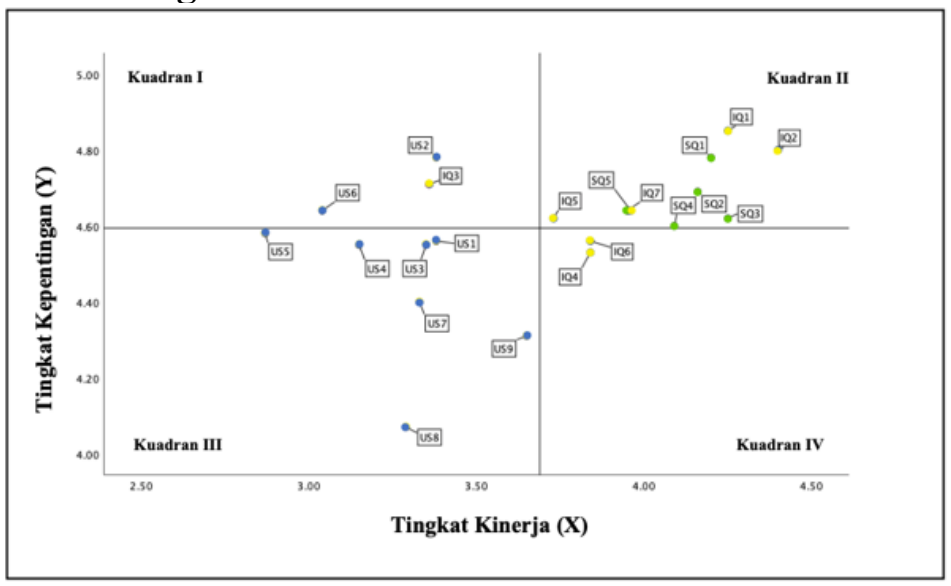

Gambar 7 Tabel Indikator Penjelasan Diagram Kartesius

Melalui proses analisis pada diagram Kartesius di atas, didapatkan titik-titik atribut yang tersebar di dalam empat bagian kuadran. Pada kuadran I (Concentrate These/Prioritas Utama), terdapat tiga atribut yang akan menjadi prioritas utama dalam perbaikan kualitas website kedepannya dan kuadran II (Keep Up The Good Work/ Pertahankan Kinerja), sembilan atribut yang harus terus dipertahankan kinerjanya. Lalu pada kuadran III (Low Priority/Prioritas Rendah), terdapat tujuh atribut yang tidak dianggap penting oleh penggunda dan pada kuadran IV (Possible Overkill/ Berlebihan) terdapat dua atribut yang telah memberikan kepuasan lebih bagi pengguna website.

Berdasarkan diagram diatas maka diperoleh saran bagi pengembang untuk dapat mengurangi informasi - informasi yang dirasa tidak diperlukan sehingga pengguna dapat lebih fokus dan mendapatkan pengalaman yang mudah ketika menggunakan website Badan Pusat Statistik (BPS). Pengembang juga dapat memberikan panduan berupa pop up guidance atau coach- mark yang akan muncul ketika pertama kali website dibuka, sehingga pengguna dapat lebih mudah memahami navigasi dari website Badan Pusat Statistik (BPS).

Dari sisi kebaharuan data, pengembang dapat terus melakukan pembaharuan pada data statistik yang disajikan. Sehingga data statistik yang diperoleh pengguna adalah data yang terkini dan dapat mendukung penelitian dengan lebih maksimal.

\section{Simpulan}

Melalui penelitian analsisis kualitas website Badan Pusat Statistik (BPS) dengan menggunakan metode WebQual 4.0 dan Importance - Performance Analysis (IPA) telah didapatkan kesimpulan berikut ini : 
1. Uji tingkat kesesuaian terhadap nilai tingkat kinerja dan kepentingan dari website Badan Pusat Statistik (BPS) memberikan hasil 87.1\% dimana nilai tersebut kurang dari $100(<100)$. Sehingga dapat disimpulkan bahwa tingkat kinerja website Badan Pusat Statistik (BPS) belum mencapai titik kepuasan penggunanya.

2. Uji nilai kesenjangan (GAP) menunjukkan hasil sebesar - 0.57 yang artinya terdapat kesenjangan diantara harapan atau ekspektasi dan kepuasan pengguna terhadap website Badan Pusat Statistik (BPS) saat ini.

3. Diagram Kartesius menunjukkan beberapa hal dalam kuadaran I (Concentrate TheseI/ Prioritas Utama) yang perlu menjadi prioritas utama dalam melakukan perbaikan dan peningkatan kualitas website Badan Pusat Statistik (BPS) untuk dapat melayani kebutuhan akan data statistik masyarakat dengan menjadi website yang lebih mudah digunakan, memiliki navigasi atau arahan dalam pengunaan yang lebih mudah dipahami dan juga data yang lebih up to date.

\section{Daftar Pustaka}

[1] BPS RI, “Analisis Hasil Survei Kebutuhan Data 2019”.

[2] bps.go.id, "Visi Misi BPS." https://www.bps.go.id/menu/1/visi-danmisi.html\#masterMenuTab2 (accessed Jan. 10, 2021).

[3] Y. Andre and K. Gianina Tileng, "Analisis Kualitas Website Perpustakaan Universitas Ciputra Surabaya Menggunakan Metode Webqual 4.0 dan ImportancePerformance Analysis (IPA)," AITI: Jurnal Teknologi Informasi, vol. 16, no. Februari, pp. 49-64, 2019.

[4] Dafied and D. Novita, "Metode WebQual 4.0 Untuk Analisis Kualitas Web Pembelajaran," JTKSI, vol. 1, no. 2, pp. 17-20, 2018.

[5] L. A. Utami, A. Gani, and S. Suparni, "Penerapan Metode Webqual 4.0 dan IPA Dalam Mengukur Kualitas Website VISLOG PT. Citra Surya Indonesi," Komputika: Jurnal Sistem Komputer, vol. 9, no. 1, pp. 25-34, Apr. 2020, doi: 10.34010/komputika.v9i1.2849.

[6] R. Kemala, D. Siregar, and R. A. Fitriawan, "Analisis Kualitas Website Ruangguru.com Menggunakan WebQual 4.0 dan IPA (Importance Performance Analysis)".

[7] bps.go.id, “Statistik Pengguna ." https://www.bps.go.id/menu/7/statistikpengguna.html. (accessed Jan. 10, 2021).

[8] D. Syukwansyah, "Pengembangan Bisnis Joeragan dengan Menggunakan Pendekatan Prinsip Efektual," 2016.

[9] D. Islamiati and H. Mentara, "Hubungan Dismenore Primer Terhadap Aktivitas Olahraga Remaja Putri di SMP Negeri 1 Banawa Tengah," Tadulako Journal Sport 
Sciences and Physical Education, vol. 7, 2019, [Online]. Available: http://jurnal.untad.ac.id/jurnal/index.php/PJKR/index

[10] E. Suryani, M. T. Departemen, M. Teknologi, B. Keahlian, I. Fakultas, and B. Dan, "Analisis Kepuasan Pengguna Pada Situs Gotomalls.com Menggunakan Metode WebQual Irianto Bunga Pratama 9112205407 Dosen Pembimbing," 2017.

[11] V. H. Pranatawijaya, W. Widiatry, R. Priskila, and P. B. A. A. Putra, "Penerapan Skala Likert dan Skala Dikotomi Pada Kuesioner Online," Jurnal Sains dan Informatika, vol. 5, no. 2, pp. 128-137, Dec. 2019, doi: 10.34128/jsi.v5i2.185.

[12] P. Celebrity et al., "Pengaruh Celebrity Endorser Hamidah Rachmayanti Terhadap Keputusan Pembelian Produk Online Shop Mayoutfit di Kota Bandung."

[13] T. Loanata and K. Gianina Tileng, "Pengaruh Trust dan Perceived Risk pada Intention To Use Menggunakan Technology Acceptance Model (Studi Kasus Pada Situs E-Commerce Traveloka)," 64 Juisi, vol. 02, no. 01, 2016.

[14] N. S. Prabowo and A. Fathoni, "Pengaruh Kepuasan Kerja dan Stress Kerja Terhadap Engagement Employee dengan Turnover Intention Sebagai Variabel Intervening Pada PT Ara Shoes Semarang."

[15] Y. Andre, "Analisis Kualitas Website Perpustakaan Univesitas Ciputra Surabaya Menggunakan Metode WebQual 4.0 dan Importance-Performance Analysis (IPA)." 